\title{
Induction of Resistance with Benzothiadiazole in Sunflower: a Comparison of Biotrophic vs. Necrotrophic Pathosystems
}

\author{
K. KÖRÖSI ${ }^{1 *}, F$. VIRÁNYI ${ }^{1}$, B. BARNA ${ }^{2}$ and R. BÁN ${ }^{1}$ \\ ${ }^{1}$ Plant Protection Institute, Szent István University, Páter K. u. 1, H-2100 Gödöllö, Hungary \\ ${ }^{2}$ Plant Protection Institute, Centre for Agricultural Research, Hungarian Academy of Sciences, \\ Herman O. út 15, H-1022 Budapest, Hungary
}

(Received: 9 November 2015; accepted: 14 January 2016)

\begin{abstract}
In the present work we aimed at comparing the effect of benzothiadiazole (BTH) treatment on defence reactions of sunflower plants to downy mildew and white rot diseases. BTH treatment resulted in reduced disease symptoms in biotrophic and in the early stage of the necrotrophic interactions. To get a better insight into the effect of BTH, changes in the activities of polyphenol oxidase and peroxidase enzymes, as well as the expression of the host response-associated sunflower genes were examined in the plants. Inoculation with Plasmopara halstedii enhanced the polyphenol oxidase and peroxidase enzyme activities, while inoculation with Sclerotinia sclerotiorum did it only at 4 dpi. However, most importantly, in each case extracts from BTH pretreated and inoculated plants showed the highest polyphenol oxidase and peroxidase enzyme activities. Similarly, the accumulation of GST and PDF transcripts was detected following inoculations with both biotrophic and necrotrophic pathogens, and again, BTH pre-treatment enhanced GST and defensine gene activities in the inoculated plants. We suggest that induction of enzyme activities, as well as of the elevated expression of GST, PDF and PR5 genes by BTH pre-treatment may be a significant part of the induced resistance of sunflower to downy mildew and white rot (white mold).
\end{abstract}

Keywords: Plasmopara halstedii, Sclerotinia sclerotiorum, downy mildew, white rot, polyphenol oxidase, guaiacol peroxidase, glutathione S-transferase.

Biotrophic and necrotrophic plant pathogens usually follow different strategies in their life-cycles: biotrophs derive materials from living plant tissues, while necrotrophs kill their hosts for nutrients (Agrios, 1997). The gene-for-gene resistance is a well-known system working among many biotrophic host-pathogen interactions in which salicylic acid- (SA) dependent defense mechanisms are thought to act against the invader pathogen (McDowell and Dangl, 2000; Glazebrook, 2005). The obligate oomycete, Plasmopara halstedii and its sunflower host represent a good example of biotrophic interaction. In contrast, necrotrophs, like Sclerotinia sclerotiorum kill host cells at a very early stage of the infection and cause extensive tissue damage (Saharan and Mehta, 2008). Affected sunflower plants, in turn, produce phenolic compounds during pathogenesis (Hemery-Tardin

\footnotetext{
* Corresponding author; e-mail: korosi.katalin@mkk.szie.hu
} 
et al., 1998), permitting the host to increase its resistance against the fungus (Bazzalo et al., 1985).

The two sunflower pathogens, Plasmopara halstedii (Farl.) Berl. et de Toni and Sclerotinia sclerotiorum (Lib.) de Bary causing severe downy mildew and white rot diseases, respectively, are of worldwide prevalent. Although $P$. halstedii can be effectively controlled by using resistant cultivars and seed dressing with fungicides, protection may be hindered by the high genetic variability of this oomycete (Albourie et al., 1998; Roeckel-Drevet et al., 1998; Gulya, 2007). S. sclerotiorum is one of the most devastating and cosmopolitan soil-borne plant pathogens that infects more than 500 plant species incl. sunflower worldwide. The fungus causes soft rot of the affected host tissues and is able to survive in the soil for many years as hard sclerotia, making the disease management particularly difficult (Abawi and Grogan, 1975; Purdy, 1979). Despite of intensive breeding programs carried out for white rot resistance in several countries, there are no resistant cultivars yet in the practice against this disease.

Since control measures against these two pathogens are not satisfactory (white mold) or limited (downy mildew), alternative and supplementary methods are required. One of the promising alternative methods could be to activate the host natural defense system by applying resistance inducer compounds, such as benzothiadiazole (BTH). Our earlier studies showed that BTH significantly reduced the appearance of downy mildew symptoms and enhanced some defense-related enzyme activities in susceptible sunflowers (Körösi et al., 2011).

In general, SA induces defense against biotrophs, whereas jasmonic acid (JA) activates defense against necrotrophs (Spoel and Dong, 2009). Furthermore, Glazebrook (2005) showed that SA and JA were also inhibitors for the expression of many genes. On the other hand, Kunkel and Brooks (2002) found that some genes could be induced both by exogenous SA and JA treatments.

An early and regular reaction of plants to abiotic or biotic stresses is the rapid accumulation of reactive oxygen species (ROS). Accumulation of ROS was detected in incompatible, but not in compatible plant-pathogen interactions in case of biotrophic pathogens (Hückelhoven and Kogel, 1998). Similarly, the rapid accumulation of ROS and the induction of antioxidant enzymes were also demonstrated by Körösi et al. (2011) in the resistant reaction of sunflower to the biotrophic downy mildew infection. In contrast, ROS generally promote pathogenic growth of necrotrophs. To eliminate the harmful effect of ROS, enzymatic and non-enzymatic antioxidants are induced in plants (Baker and Orlandi, 1995; Wojtaszek, 1997; Apel and Hirt, 2004; Király et al., 2007).

Guaiacol peroxidase (POX, EC 1.11.1.7) and polyphenol oxidases (PPO, EC 1.10.3.2 or EC 1.14.18.1) are thought to be associated with host defense mechanisms in plants. Peroxidases are oxido-reductive enzymes that participate in the cell wall building processes such as oxidation of phenols, suberization and lignification of host plant cells during defense reactions against pathogens (Chittoor et al., 1999). In addition, plant peroxidases eliminating $\mathrm{H}_{2} \mathrm{O}_{2}$ in oxidation reactions may have a role in plant resistance to some diseases (Pereira et al., 2000). The involvement of POX in stress-related physiological processes as well as in plant-pathogen interactions was also demonstrated by Wojtaszek (1997), but very few data are available so far for the P. halstedii-sunflower 
pathosystem (Roeckel-Drevet et al., 1998; Herbette et al., 2003). Polyphenol oxidases are involved in the oxidation of polyphenols into quinones and in lignification of plant cells. These enzymes were suggested to participate in plant defense reactions by Constabel et al. (1995) and Thipyapong et al. (1995). Glutathione S-transferase (GST) has a significant role in plant detoxification reactions, as well. It is capable of catalysing the binding of various xenobiotics with glutathione. Enhanced GST activity has been found in plants after pathogen infection, e.g. in barley plants infected with powdery mildew (El-Zahaby et al., 1995; Harrach et al., 2008) and tobacco plants infected with tobacco mosaic virus (Fodor et al., 1997).

To protect themselves against pathogen attack, plants have evolved diverse strategies, including the synthesis of antimicrobial peptides like defensin, which exists in a wide range of plants and animals. Urdangarin et al. (2000) described full-length cDNA encoding defensin from Helianthus annuus (sunflower), and they proved a relationship between the defensin gene activity and resistance to $S$. sclerotiorum. In addition, Solis et al. (2007) isolated a defensin gene from Lepidium meyenii which exerts an inhibitory effect against Phytophthora infestans infection. Pathogenesis related (PR) proteins are well-known proteins induced by various pathogens. Fourteen classes of PR protein (PR1PR14) are currently recognized in plants. In Arabidopsis thaliana, PR1, PR2 (a $\beta$-1,3-glucanase) and PR5 (thaumatin) are induced by salicylic acid in response to biotrophic pathogens, whereas PR3, PR4 (chitinases) and PR12 (a defensin) are induced by JA in defence against necrotrophic pathogens (Spoel and Dong, 2012).

In order to apply induced resistance as a protection measure against these pathogens more information is needed on the underlying mechanisms in host-parasite interactions as well as on the effectiveness of inducers. Goals of the present study were to examine the effectiveness of BTH in sunflower against $S$. sclerotiorum and to compare the mechanisms of induced resistance in case of a biotrophic ( $P$. halstedii) and a necrotrophic (S. sclerotiorum) pathosystem.

\section{Materials and Methods}

\section{Plants and pathogens}

The sunflower inbred line RHA-274 (USDA) (exhibiting no resistance to $P$. halstedii pathotype 700) and the Hungarian open pollinated sunflower cultivar, Iregi szürke csíkos, having no resistance to $S$. sclerotiorum, were the plant material. RHA-274 is generally used in the processes of race (pathotype) identification of $P$. halstedii. It is susceptible to many $P$. halstedii races (e.g., 700, 704, 714, 734, etc.) and confers resistance to others such as races 100, 300 and 330 (Jocić et al., 2012). Iregi szürke csíkos is a Hungarian sunflower cultivar is highly susceptible to all known races of $P$. halstedii and has a moderate susceptibility to $S$. sclerotiorum.

P. halstedii pathotype 700, and an isolate of S. sclerotiorum (SZ 24 strain) both from the Szent István University collection were used to get compatible plant-pathogen interactions (Virányi and Gulya, 1996). 


\section{BTH treatment and pathogen infections}

Sunflower seeds were surface sterilized in a $15 \%$ Na-hypochlorite solution for 3-5 min, then rinsed thoroughly with running tap water and germinated on moist filter paper at room temperature until 3-5 mm long root initials had developed (2 days).

The pre-germinated seeds were soaked in a $160 \mathrm{mg} / \mathrm{L}$ aqueous solution of BTH (Bion 50 WG, Syngenta, Hungary) for 6 h. Control was treated with water only.

Inoculation of sunflower plants with $P$. halstedii pathotype 700 was performed 1 day after BTH treatment using a method described by Cohen and Sackston (1973). Three day-old seedlings were soaked in a freshly prepared suspension of P. halstedii sporangia for $5 \mathrm{~h}$ using a spore density of 50,000 sporangia/ml. Then the seedlings were planted in pots filled with a commercial soil mixture and grown in a glasshouse at $18-25^{\circ} \mathrm{C}$ and a $16 \mathrm{~h}$ photoperiod for 3 weeks.

For the white rot experiment, pre-germinated seeds were treated with BTH as described above, then planted in soil and grown in a glasshouse at the above conditions up to the two-leaf stage, since earlier infection with $S$. sclerotiorum had lethal effect on sunflower seedlings. S. sclerotiorum SZ 24 was grown on tomato dextrose agar plates, and mycelial discs of $8 \mathrm{~mm}$ diameter were cut off from one-week-old culture using a cork borer. Then the discs were placed on the bases of the hypocotyl parts of plants (one disc/ plant). Accordingly, the following treatments were used:

- untreated and uninfected control (C);

- BTH-treated only (BTH);

- inoculated with P. halstedii or S. sclerotiorum (I);

- pre-treated with BTH and inoculated with one of the pathogens $(\mathrm{BTH}+\mathrm{I})$.

\section{Disease assessment}

In case of downy mildew, plants were sprayed with distilled water eight days after inoculation and covered with plastic bags over night to induce sporulation. Disease assessment was made by using a 0-4 scale, where the proportion of cotyledon leaf area covered by sporangia was graded as no sporulation (0), <25\% (1), 25\%-75\% (2), > 75\% (3) and $100 \%$ (4), respectively (Oros and Virányi, 1987).

In case of $S$. sclerotiorum a 0-3 scale was used to assess the severity of infection at 2, 4 and 7 days after inoculation as follows: no symptoms (0), brown rot on the stem base, plant is still standing (1), plant is wilted (2), plant is died (3).

\section{Enzyme extraction and assay}

Enzyme activities were determined spectrophotometrically. For the detection of oxido-reductive enzyme activities, $0.5 \mathrm{~g}$ of the whole hypocotyl tissue was homogenized at $0-4{ }^{\circ} \mathrm{C}$ in $3 \mathrm{ml}$ of TRIS- $\mathrm{HCl}$ buffer $(50 \mathrm{mM}, \mathrm{pH} 7.8)$ containing $1 \mathrm{mM}$ EDTA-Na and $7.5 \%(\mathrm{w} / \mathrm{v})$ soluble polyvinylpyrrolidone (Sigma-Aldrich Co.). The suspension was centrifuged at $10,000 \mathrm{~g}$ for $20 \mathrm{~min}$ at $4{ }^{\circ} \mathrm{C}$. The supernatant was kept on melting ice and used for enzyme assay. All measurements were performed at $25^{\circ} \mathrm{C}$, using a SmartSpec 


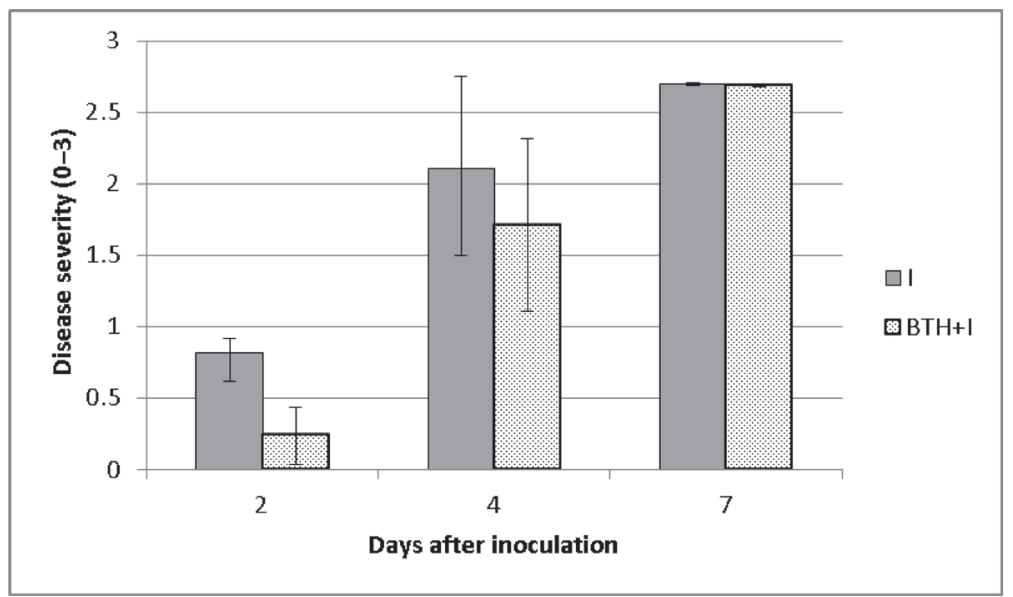

Fig. 1. Effect of BTH treatment on the Sclerotinia sclerotiorum-infected, susceptible sunflower plants (cv. Iregi szürke csíkos). Disease development was rated by using the following scale: 0 , no symptoms; 1 , brown rot on the stem base, plant is still standing; 2, plant is wilted, laying on the ground; 3, plant is died. I - inoculated, $\mathrm{BTH}+\mathrm{I}-$ treated and inoculated. Columns represent mean values $\pm \mathrm{SD}(n=50)$

Plus Spectrophotometer (BioRad). Since disease development was faster in the case of white rot than downy mildew, sampling period was shorter from S. sclerotiorum inoculated plants. Samples for enzyme assays were harvested from 4-, 8- and 14-day-old plants inoculated with $P$. halstedii and from 23-, 25- and 28-day-old plants at 2, 4 and 7 days after inoculation with $S$. sclerotiorum, respectively (Fig. 1).

PPO activity was determined by measuring the rate of quinone formation, as indicated by an increase in absorbance at $400 \mathrm{~nm}$, using the procedure described by Fehrmann and Dimond (1967). Briefly, the reaction mixture contained $2.2 \mathrm{ml}$ potassium-phosphate buffer (0,1 M, pH 6.0), $1 \mathrm{mM}$ EDTA-Na, $20 \mathrm{mM}$ catechol and $200 \mu 1$ plant extract. The measurement lasted 160 seconds the activity was calculated using the extinction coefficient of the formed product $\left(950 \mathrm{M}^{-1} \mathrm{~cm}^{-1}\right)$. The guaiacol-dependent peroxidase (POX) activity was determined following a method described by Rathmell and Sequeira (1974). The reaction mixture contained $2.2 \mathrm{ml}$ potassium-phosphate buffer $(0.1 \mathrm{M}, \mathrm{pH} 6), 100 \mu 1$ of $50 \mathrm{mM}$ guaiacol, $100 \mu \mathrm{l}$ of $12 \mathrm{mM} \mathrm{H}_{2} \mathrm{O}_{2}$, and $100 \mu \mathrm{l}$ plant extract. The measurement lasted 160 seconds, the activity was calculated using the extinction coefficient of the formed product $\left(26.6 \mathrm{mM}^{-1} \mathrm{~cm}^{-1}\right)$.

\section{Semi-quantitative RT-PCR}

The whole seedlings were frozen in liquid nitrogen and ground with mortar and pestle. Total RNA was extracted with Qiagen Plant Mini Kit, treated with DNase I (Fermentas) and reverse transcribed using iScript cDNA Synthesis Kit (BioRad) according to the manufacturers' instructions. 
Table 1

Primer sequences and accession numbers used in this study

\begin{tabular}{|c|c|c|}
\hline Gene & Primer sequence & Accession number \\
\hline$H a-E F-1 \alpha$ & $\begin{array}{l}\text { Forward 5'-AGGCGAGGTATGATGAAATTGTCA-3' } \\
\text { Reverse 5'-GTCTCTTGGGCTCATTGATTTGGT-3' }\end{array}$ & AAM19764 \\
\hline$H a-G S T$ & $\begin{array}{l}\text { Forward 5'-CCTCAGGATGCTTACGAGAAGG-3' } \\
\text { Reverse 5'-GCAGAAATATCAACCAGGTTGATG-3' }\end{array}$ & AY667502 \\
\hline$H a-P D F$ & $\begin{array}{l}\text { Forward 5'-ATGGCCAAAATTTCAGTTGCTTTCA-3' } \\
\text { Reverse 5'-AAGACTTGCACTGGTCATCACAG-3' }\end{array}$ & AF364865 \\
\hline$H a-P R 5$ & $\begin{array}{l}\text { Forward 5'-GGATGCAACAATCCTTGCACGG -3' } \\
\text { Reverse 5'-TGGTCGGGTCATCTTGAGGG -3' }\end{array}$ & AF364864 \\
\hline
\end{tabular}

$H a-E F-1 \alpha$ : constitutive elongation factor $1 \alpha$; Ha-GST: glutathione S-transferase; Ha-PDF: defensin; Ha-PR5: PR5 gene

Primers for PCR amplifications were used according to Radwan et al. (2005). The primers were denoted as follows: $H a-E F-1 \alpha$, sunflower constitutive elongation factor $1 \alpha$; $H a-G S T$, sunflower glutathione S-transferase; $H a-P D F$, sunflower defensin; and Ha-PR5, sunflower PR5 gene (Table 1).

PCR reactions were performed using a Gene Amp PCR System 2700 PCR machine, and Taq Polimerase (Fermentas). The amplification program included an initial step at $94{ }^{\circ} \mathrm{C}$ for $3 \mathrm{~min}$ and 25-32 cycles (Ha-EF-1 $\alpha$, 25; Ha-GST, 26; Ha-PDF, 30; Ha$P R 5,29)$ each of $15 \mathrm{~s}$ at $94{ }^{\circ} \mathrm{C}$, and $15 \mathrm{~s}$ at $\mathrm{Tm}{ }^{\circ} \mathrm{C}(\mathrm{Ha}-\mathrm{EF}-\mathrm{l \alpha}, 58 ; \mathrm{Ha}-\mathrm{GST}$ and Ha-PDF, 61; Ha-PR5, 64), and $20 \mathrm{~s}$ at $72{ }^{\circ} \mathrm{C}$.

The PCR products were separated by electrophoresis in $1 \%$ agarose gels, visualized with ethidium bromide and images were captured in a molecular imager gel doc system (BioRad). The signals from gels were quantified using a Quantity One program using a molecular mass ruler, and normalized over the signals from Ha-EF-1 $\alpha$.

\section{Statistical analyses}

All experiments were carried out twice, with each experiment containing three replicates, and data were subjected to ANOVA $(\alpha=0.05)$ using the Fisher's multiple comparison with the MINITAB statistical package (version 10.2).

\section{Results}

Disease symptom appearance

The untreated and inoculated susceptible plants (RHA-274) showed typical downy mildew symptoms, including fungal sporulation and damping off, whereas BTH treatment significantly reduced sporulation on cotyledons, and reduction of stunting. 
In case of white rot, disease rates on BTH treated plants were slightly lower than on non-treated plants. Infected plants (either treated or not) showed some rotting at stem base and began to wilt, while BTH treatment reduced $S$. sclerotiorum symptoms at 2 and 4 dpi (Fig. 1), but the differences were not significant at 4 dpi. At 7 days after infection, however, the infected plants showed severe rotting and significant differences were not detected between the treated and non-treated plants (Fig. 1). Thus the BTH treatment only delayed the disease development caused by the necrotrophic pathogen.

Changes in enzyme activities over time following BTH treatment and/or inoculation PPO activity

BTH treatment alone enhanced significantly (except at 14 dpi) PPO enzyme activity in the RHA-274 line, and the inoculation of the susceptible sunflower line with $P$. halstedii also increased PPO activity (Fig. 2). In case of Iregi szürke csíkos cultivar the activator treatment had no effect on the PPO activity (there were no significant differences between the control and the BTH-treated plants), and inoculation (infection) with S. sclerotiorum elevated PPO activity, but significant differences were measured only at $4 \mathrm{dpi}$, as compared to the noninfected control (Fig. 3). Similarly, BTH treatment alone enhanced significantly (except at 14 dpi) PPO enzyme activity in the RHA-274 line, while it had no effect on the Iregi Szürke Csíkos cultivar (there were no significant differences between the control and the BTH-treated plants).

On the other hand, both infections of the BTH pretreated plants with the biotrophic and necrotrophic pathogens strongly increased PPO activity as compared to the control ones, although the induction of activity was only about 50-80\% in the biotrophic (Fig. 2) and about $400-500 \%$ in the necrotrophic interaction as compared to the nontreated and noninfected control (Fig. 3).

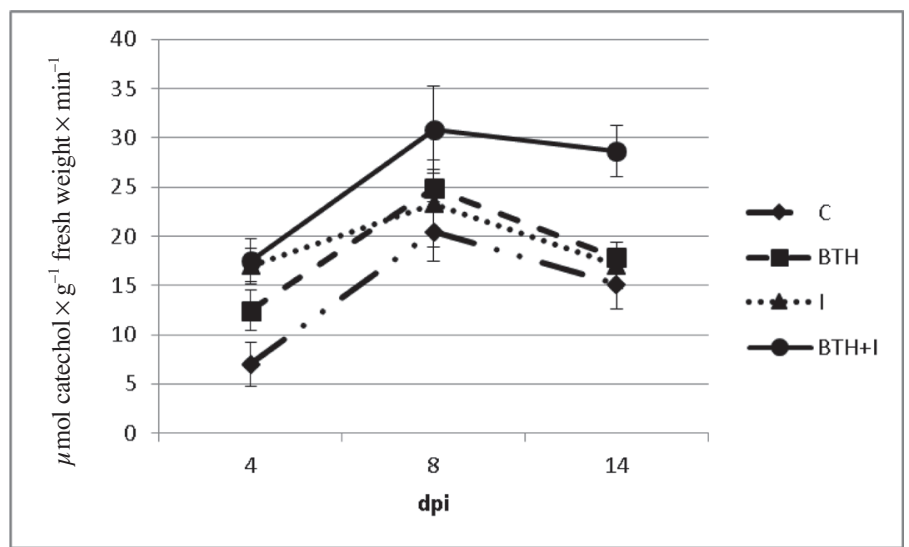

Fig. 2. Polyphenol-oxidase activity $\left(\mu \mathrm{M}\right.$ catechol $\times \mathrm{g}^{-1}$ fresh weight $\left.\times \min ^{-1}\right)$ in susceptible sunflower (RHA 274) after BTH treatment and Plasmopara halstedii inoculation. Means of two independent experiments are shown $( \pm \operatorname{SD})(n=6)$. $\mathrm{C}$ - control, BTH - BTH-treated, I - inoculated, BTH + I - BTH treated and inoculated 


\section{POX activity}

BTH-treatment resulted in enhanced POX activities in both sunflower lines. In nontreated sunflower plants, $P$. halstedii increased POX activity throughout the experiment, while the necrotroph $S$. sclerotiorum resulted in a significant increase in the enzyme activity only at 4 days post inoculation (dpi) (Figs 4, 5). The highest enzyme activities

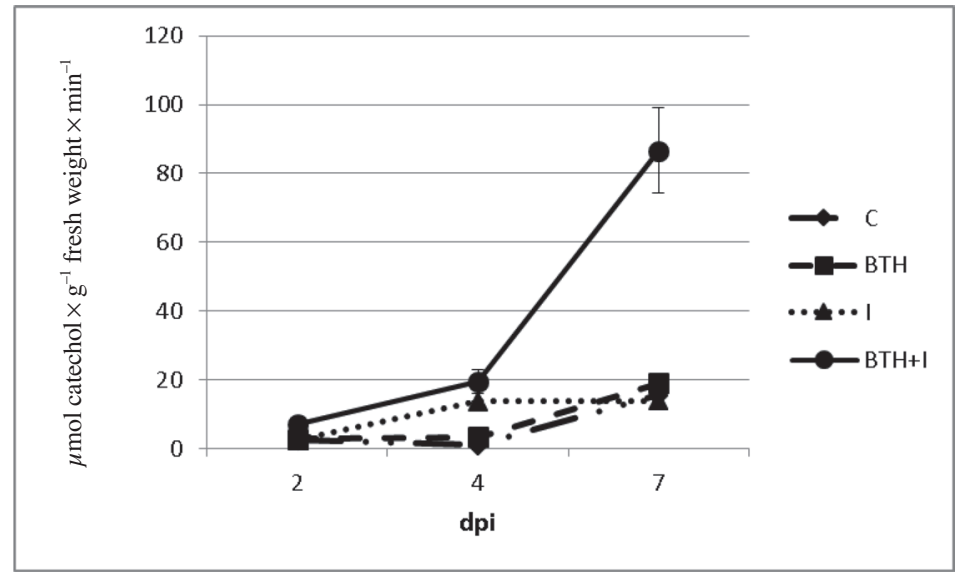

Fig. 3. Polyphenol-oxidase activity $\left(\mu \mathrm{M}\right.$ catechol $\times \mathrm{g}^{-1}$ fresh weight $\left.\times \min ^{-1}\right)$ in susceptible sunflower (cv. Iregi szürke csíkos) after BTH treatment and Sclerotinia sclerotiorum inoculation. Means of independent experiments are shown $( \pm \mathrm{SD})(n=6) . \mathrm{C}-$ control, BTH - BTH-treated, I - inoculated, BTH+I - BTH treated and inoculated

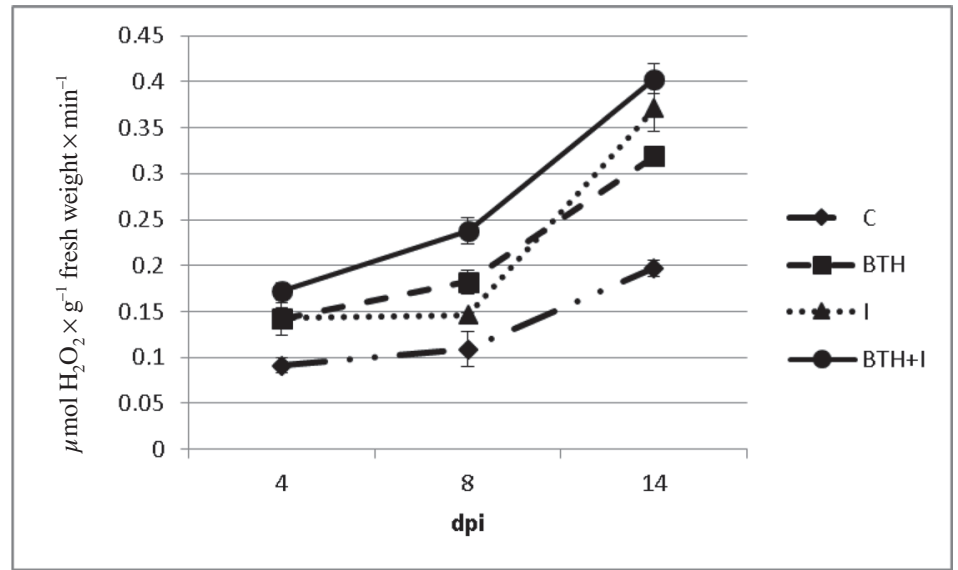

Fig. 4. Guaiacol-peroxidase activity $\left(\mu \mathrm{M} \mathrm{H}_{2} \mathrm{O}_{2} \times \mathrm{g}^{-1}\right.$ fresh weight $\left.\times \min ^{-1}\right)$ in susceptible sunflower (RHA 274) after BTH treatment and Plasmopara halstedii inoculation. Means of two independent experiments are shown $( \pm \mathrm{SD})(n=6) . \mathrm{C}-$ control, BTH $-\mathrm{BTH}$-treated, I - inoculated, BTH + I $\mathrm{BTH}$ treated and inoculated 
were measured in the BTH-treated and inoculated plants both in the biotrophic and necrotrophic plant-pathogen interactions, and again the increase was much higher in the case of white rot (about twice) than in the case of downy mildew (about twice) as compared to the control (Figs 4, 5).

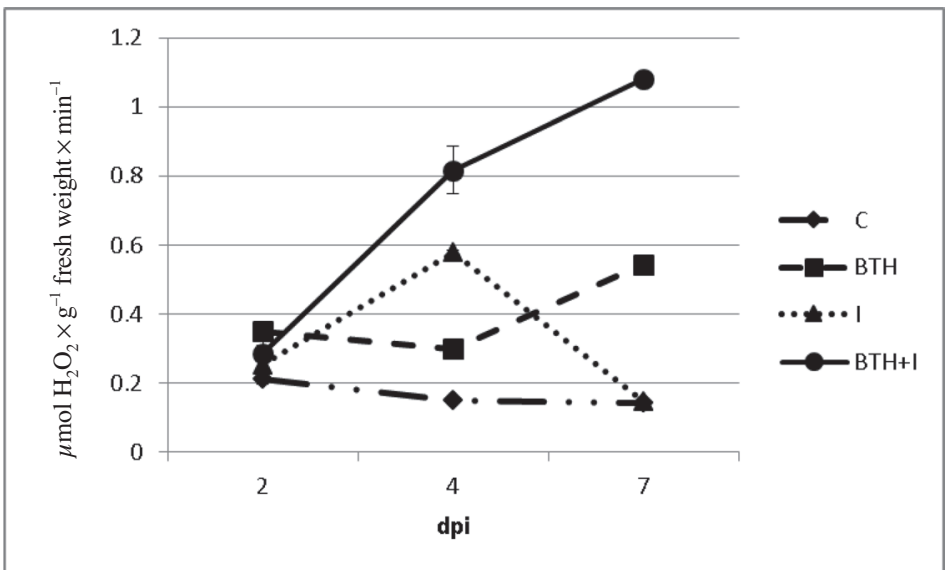

Fig. 5. Guaiacol-peroxidase activity $\left(\mu \mathrm{M} \mathrm{H}_{2} \mathrm{O}_{2} \times \mathrm{g}^{-1}\right.$ fresh weight $\left.\times \min ^{-1}\right)$ in susceptible sunflower (cv. Iregi szürke csíkos) after BTH treatment and Sclerotinia sclerotiorum inoculation. Means of two independent experiments are shown $( \pm \mathrm{SD})(n=6)$. C - control, BTH $-\mathrm{BTH}$-treated, I - inoculated, $\mathrm{BTH}+\mathrm{I}-\mathrm{BTH}$ treated and inoculated

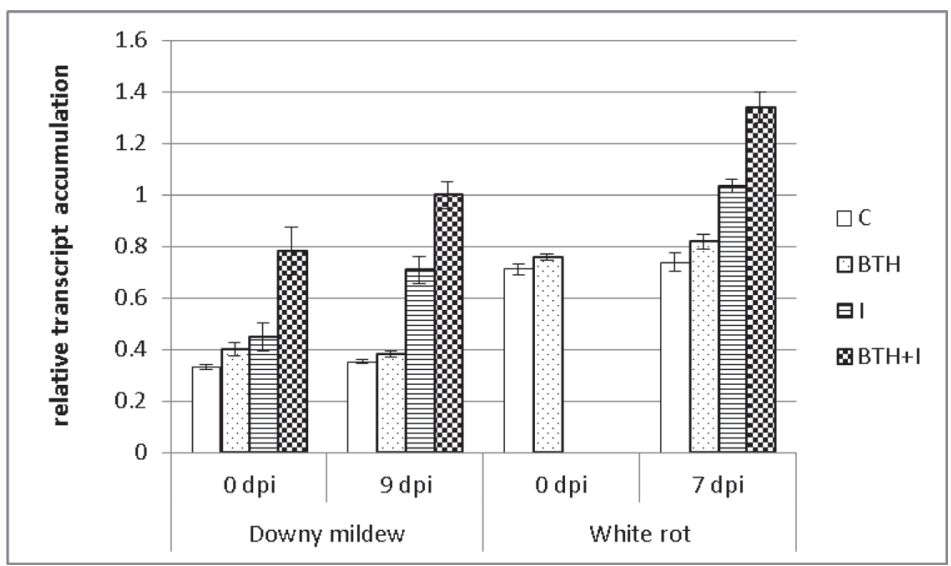

Fig. 6. Sunflower glutation-S transferase (Ha-GST) transcript accumulation in susceptible sunflower (RHA 274/cv. Iregi szürke csíkos) after BTH treatment and/or Plasmopara halstedii/Sclerotinia sclerotiorum inoculation. The signals

from ethidium bromide-stained gels were quantified using a Quantity one program (Bio-Rad) and normalized over the signals from constitutive probes sunflower elongation factor $1 \alpha(H a-E F-1 \alpha)$. Each value represents the means of signal intensities $\pm \mathrm{SD}(n=3)$. C - control, BTH - BTH-treated, $\mathrm{I}-$ inoculated, BTH+I $-\mathrm{BTH}$ treated and inoculated 


\section{Defense-associated gene expressions}

\section{GST}

As for changes in the Ha-GST transcript accumulation, already in 0 dpi BTHtreated and $P$. halstedii inoculated plants showed significantly higher gene activity, than the nontreated, only inoculated ones. The inoculation by either biotrophic or necrotrophic pathogen significantly enhanced the accumulation of gene products in both pathosystems (Fig. 6).

The highest, significant increases in transcript accumulation were detected in the BTH-treated and P. halstedii or S. sclerotiorum-inoculated sunflower plants. The noninoculated plant's gene activity remained stable in the whole experiment (Fig. 6).

PDF

$P D F$ gene was only expressed in inoculated sunflowers, whereas no transcript accumulation could be detected in the non inoculated plants. BTH treatment enhanced significantly the PDF gene expression in both type of interactions, and this increase was somewhat more prominent with the $P$. halstedii-inoculated plants, as compared to the S. sclerotiorum-inoculated ones (Fig. 7).

\section{PR-5}

There was no $P R-5$ gene activity in the noninoculated sunflower plants either treated or not with BTH. Even, this gene was only expressed in the plants inoculated by $S$. sclerotiorum, but not in the P. halstedii-inoculated ones. We could not detect significant differences between the BTH treated and nontreated, inoculated plants (Fig. 8).

\section{Discussion}

Our aim was to investigate the effect of BTH pre-treatment on downy mildew and white rot diseases in susceptible sunflower plants, and to get a deeper insight into the mechanisms of this type of induced resistance. Since POX and PPO are suggested to be associated with host defense mechanisms in plants, we examined the activity of these two oxido-reductive enzymes in an experimental system where sunflower plants susceptible to $P$. halstedii and $S$. sclerotiorum were pre-treated or not with BTH and then inoculated or not with one of these pathogens. BTH successfully induced resistance in sunflower to the biotrophic pathogen, but only delayed disease development caused by the necrotrophic S. sclerotiorum (Fig. 4). The reason for the less effectiveness of BTH pre-treatment to $S$. slerotiorum is probably due to the strong virulence of our isolate used in the experiments. It is noteworthy that BTH treatment alone increased both PPO and POX enzyme activities in the noninoculated RHA 274 sunflower inbred line and POX activity in Iregi szürke csíkos cultivar. In addition, both biotrophic and necrotrophic pathogen infections resulted in an increase in PPO and POX enzyme activities as compared to the non inoculated control (Figs 2, 3, 4, 5). Similar results were found earlier with biotrophic pathogens in sunflower (Serrano et al., 2007; Nandeshkumar et al., 2008). Furthermore, 


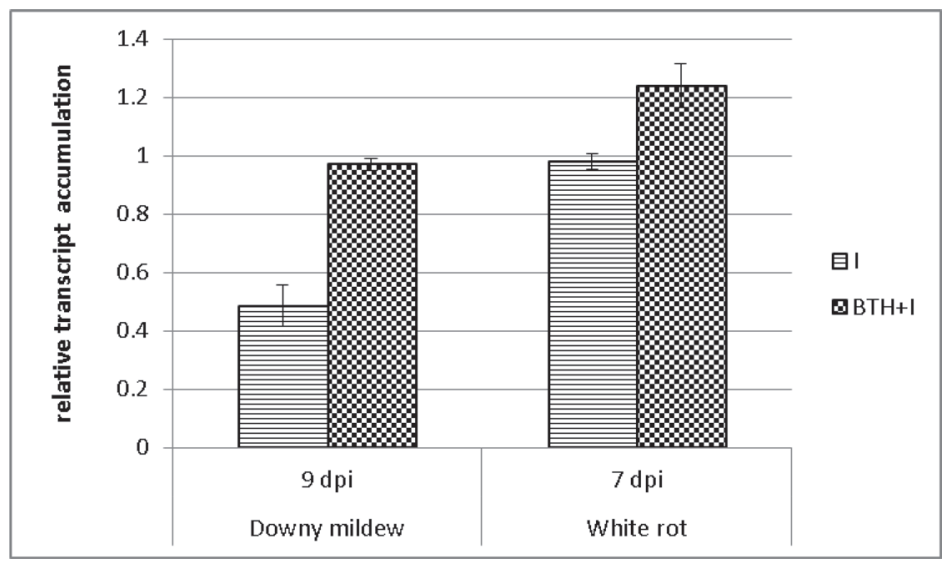

Fig. 7. Sunflower defensin $(H a-P D F)$ transcript accumulation in susceptible sunflower (RHA 274/cv. Iregi szürke csíkos) after BTH treatment and/or

Plasmopara halstedii/Sclerotinia sclerotiorum inoculation. Each value represents the means of the quantity of the signals ( $\pm \mathrm{SD})(n=3)$.

The signals from ethidium bromide-stained gels were quantified using a

Quantity one program (Bio-Rad) and normalized over the signals from constitutive probes sunflower elongation factor $1 \alpha(H a-E F-1 \alpha)$. Each value represents the means of signal intensities $\pm \mathrm{SD}(n=3)$. $\mathrm{I}-$ inoculated, BTH $+\mathrm{I}-\mathrm{BTH}$ treated and inoculated

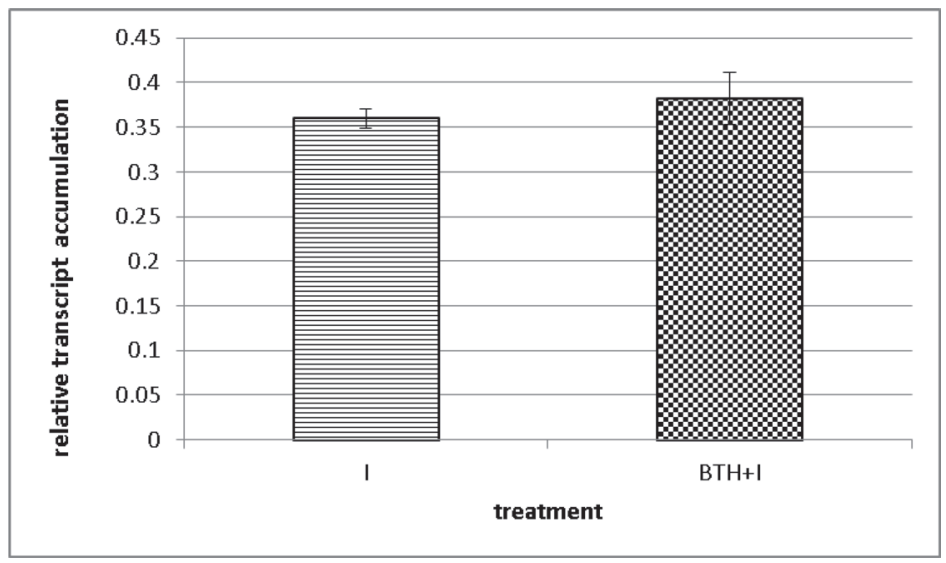

Fig. 8. Sunflower $P R-5$ (Ha-PR5) transcript accumulation in susceptible sunflower (cv. Iregi szürke csíkos) after BTH treatment and Sclerotinia sclerotiorum inoculation (7 dpi). Each value represents the means of the quantity of the signals $( \pm \mathrm{SD})(n=3)$. The signals from ethidium bromidestained gels were quantified using a Quantity one program (Bio-Rad) and normalized over the signals from constitutive probes sunflower elongation factor $1 \alpha(H a-E F-1 \alpha)$. Each value represents the means of signal intensities $\pm \mathrm{SD}(n=3)$. I - inoculated, BTH+I - BTH treated and inoculated 
Marciano et al. (1983) and Sato (1980) showed that oxalic acid exhibited high inhibitory effect on PPO activity in spinach. In accordance, in our study S. sclerotiorum-inoculated plants showed somewhat lower PPO activity as compared to P. halstedii-inoculated plants, and the high PPO activity obtained in the last sampling day ( $7 \mathrm{dpi}$ ) correlated with development of disease symptoms in case of white rot. Interestingly, S. sclerotiorum-inoculated plants showed high POX enzyme activity in the third sampling day (4 dpi), and this activity ceased with time to a level close to that of the noninoculated plants probably because of the late disintegration of diseased tissues. It is noteworthy that according to the literature some necrotrophic pathogens, like Botrytis cinerea and Rhynchosporium secalis can induce ROS at an early stage of interaction with their hosts to initiate a successful infection (Tiedemann, 1997; Govrin and Levine, 2000; Schouten et al., 2002; Able, 2003). Moreover, Malencic et al. (2010) showed that 48 hours after S. sclerotiorum inoculation the sunflower plants exhibited increased POX, and pyrogalol peroxidase activity, and these results are in line with our findings.

Furthermore, the importance of PPO in disease resistance is supported by Li and Steffens (2002), who showed that PPO overexpressing transgenic tomato plants exhibited elevated resistance to Pseudomonas syringae, when compared to the wild-type plants. Shetty et al. (2008) also demonstrated that upon pathogenic attack peroxidases and PPO were induced together with other oxido-reductive enzymes suggesting the involvement of these enzymes in disease development and resistance. In addition, accumulation of lignin and phenolic compounds has been correlated with disease resistance in some investigated plant-pathogen interactions (Bazzalo et al., 1985; Kolattukudy et al., 1992; Chittoor et al., 1999).

Most importantly, we got the highest values in the case of all investigated enzyme activities and gene expression parameters, when sunflower plants were pre-treated with BTH and inoculated either with the biotrophic, or the necrotrophic pathogen. Thus, the highest PPO and POX activities were measured when sunflower plant were pre-treated with BTH and inoculated with P. halstedii or S. sclerotiorum. It is important to note, that the strong inductions of these enzymes in BTH pre-treated and inoculated plants correlated with the induction of resistance in the case of biotrophic, and less so in the case of necrotrophic pathogen.

As expected, the accumulation of GST and PDF transcripts in sunflowers was evident following inoculations with both biotrophic and necrotrophic pathogens. In accordance, several workers showed enhanced GST enzyme activity and PDF expression after pathogen attack (Fodor et al., 1997; Radwan et al., 2005). Again, we have to emphasize, that the highest expression of all the investigated genes were measured when sunflower plants were pre-treated with BTH and inoculated with the biotrophic or necrotrophic pathogen. It is noteworthy that in our experiments BTH pre-treatment not only enhanced these gene activities, but at the same time it also induced resistance in the biotrophic pathosystem, and delayed the symptom development in the necrotrophic one. It is worth to mention, however, that Penninckx et al. (1996) showed, that PDF gene activity was not induced in Arabidopsis when SA or its analogue was applied externally. Thus, the background of $P D F$ gene activation seems to be not perfectly clear, neither in the biotrophic nor in the necrotrophic plant-parasite interactions. 
The $P R-5$ gene in our experiment was induced by the necrotrophic pathogen only. This information, however, is not surprising, because the $P R-5$ gene is known to be connected to the JA pathway, which is induced by necrotrophic pathogens (Desmond et al., 2006; Barna et al., 2012).

In conclusion, our experimental data showed that BTH pre-treatment of sunflower was capable of inducing resistance in a biotrophic, and in the early stage of a necrotrophic plant-pathogen interaction. Since increased PPO and POX enzyme activities and enhanced GST, $P D F$ and $P R-5$ gene expressions correlated with the induction of disease resistance, they probably play an important role in the induction of SAR. We think therefore that chemical resistance inducers, like BTH may be of significance in the future as being involved in sunflower disease management.

\section{Acknowledgements}

This work was kindly supported by the research grant OTKA No. 81209. and by the Research Centre of Excellence - 9878/2015/FEKUT.

\section{Literature}

Abawi, G. S. and Grogan, R. G. (1975): Source of primary inoculum and effects of temperature and moisture on infection of beans by Sclerotinia sclerotiorum. Phytopathology 65, 300-309.

Able, A. J. (2003): Role of reactive oxygen species in the response of barley to necrotrophic pathogens. Protoplasma 221, 137-143.

Agrios, G. N. (1997): Plant Pathology. Academic Press Inc., San Diego, USA, CA, 105 p.

Albourie, J. M., Tourvieille, J. and Labrouhe, D. T. (1998): Resistance to metalaxyl in isolates of the sunflower pathogen Plasmopara halstedii. Eur. J. Plant Pathol. 104, 235-242.

Apel, K. and Hirt, H. (2004): Reactive oxygen species: metabolism, oxidative stress, and signal transduction. Annu. Rev. Plant Biol. 55, 373-399.

Baker, C. J. and Orlandi, E. W. (1995): Active oxygen in plant pathogenesis. Annu. Rev. Phytopathol. 33, $299-321$.

Barna, B., Fodor, J., Harrach, B. D., Pogány, M. and Király, Z. (2012): The Janus face of reactive oxygen species in resistance and susceptibility of plants to necrotrophic and biotrophic pathogens. Plant Physiol. Biochem. 59, 37-43.

Bazzalo, M. E., Heber, E., Del Pero de Martines, M. A. and Caso, O. H. (1985): Phenolic compounds in stems of sunflower plants inoculated with Sclerotinia sclerotiorum and their inhibitory effects on the fungus. Phytopathology 112, 322-332.

Chittoor, J. M., Leach, J. E. and White, F. F. (1999): Induction of peroxidase during defense against pathogens. In: S. K. Datta and S. Muthukrishnan (eds): Pathogenesis: Related Proteins in Plants. Boca Raton, FL, CRC Press, $291 \mathrm{p}$.

Cohen, Y. and Sackston, W. E. (1973): Factors affecting infections of sunflowers by Plasmopara halstedii. Can. J. Bot. 52, 15-22.

Constabel, C. P., Bergey, D. R. and Ryan, C. A. (1995): Systemic activates synthesis of wound-inducible tomato leaf polyphenol oxidase via the octadecanoid defense signaling pathway. Plant Biol. 92, 407-411.

Desmond, O. J., Edgar, C. I., Manners, J. M., Maclean, D. J., Schenk, P. M. and Kazan, K. (2006): Methyl jasmonate induced gene expression in wheat delays symptom development by the crown rot pathogen Fusarium pseudograminearum. Physiol. Mol. Plant Pathol. 67, 171-179.

El-Zahaby, H. M., Gullner, G. and Király, Z. (1995): Effects of powdery mildew infection of barley on the ascorbate-glutathione cycle and other antioxidants in different host-pathogen interaction. Phytopathology 85, $1225-1230$. 
Fehrmann, H. and Dimond, A. E. (1967): Peroxidase activity and Phytophthora resistance in different organs of the potato plant. Phytopathology 57, 69-72.

Fodor, J., Gullner, G., Ádám, A. L., Barna, B., Kömíves, T. and Király, Z. (1997): Local and systemic responses of antioxidants to tobacco mosaic virus infection and salicylic acid in tobacco. Plant Physiol. 114, 1443-1451.

Glazebrook, J. (2005): Contrasting mechanisms of defense against biotrophic and necrotrophic pathogens. Annu. Rev. Phytopathol. 43, 205-227.

Govrin, E. M. and Levine, A. (2000): The hypersensitive response facilitates plant infection by the necrotrophic pathogen Botrytis cinerea. Current Biol. 10, 751-757.

Gulya, T. (2007): Distribution of Plasmopara halstedii races from sunflower around the world. In: A. Lebeda and P. T. N. Spencer-Phillips (eds): Advances in Downy Mildew Research, Vol. 3. OlomoucJOLA, Palacky University, pp 121-134.

Harrach, B. D., Fodor, J., Pogány, M., Preuss, J. and Barna, B. (2008): Antioxidant, ethylene and membrane leakage responses to powdery mildew infection of near-isogenic barley lines with various types of resistance. Eur. J. Plant Pathol. 121, 21-33.

Hemery-Tardin, M. C., Tourvieille de Labrouche, D., Jay, M., Ledoigt, G. and Vear, F. (1998): Effect of infection by Sclerotinia spp. on the phenolic metabolism of sunflower capitula and leaves. Helia 21, 19-32.

Herbette, S., Lenne, C., De Labrouhe, D. T., Drevet, J. R. and Roeckel-Drevet, P. (2003): Transcripts of sunflower antioxidant scavengers of the SOD and GPX families accumulate differentially in response to downy mildew infection, phytohormones, reactive oxygen species, nitric oxide, protein kinase and phosphatase inhibitors. Physiol. Plant. 119, 418-428.

Hückelhoven, R. and Kogel, K-H. (1998): Tissue-specific superoxide generation at interaction sites in resistant and susceptible near-isogenic barley lines attacked by the powdery mildew fungus (Erysiphe graminis $\mathrm{f}$. sp. hordei). Molec. Plant-Microbe Interact. 11, 292-300.

Jocić, S., Miladinović, D., Imerovski, I., Dimitrijević, S., Cvejić, S., Nagl, N. and Kondić-Špika, A. (2012): Towards sustainable downy mildew resistance in sunflower. Helia 35, 61-72.

Király, L., Barna, B. and Király, Z. (2007): Plant resistance to pathogen infection: forms and mechanisms of innate and acquired resistance. J. Phytopathol. 155, 385-396.

Kolattukudy, P. E., Mohan, R., Bajar, M. A. and Sherf, B. A. (1992): Plant peroxidase gene expression and function. Biochem. Soc. Trans. 20, 333-337.

Körösi, K., Bán, R., Barna, B. and Virányi, F. (2011): Biochemical and molecular changes in downy mildew-infected sunflower triggered by resistance inducers. J. Phytopathol. 159, 471-478.

Kunkel, B. N. and Brooks, D. M. (2002): Cross talk between signaling pathways in pathogen defense. Curr. Op. in Plant Biol. 5, 325-331.

Li, L. and Steffens, J. C. (2002): Overexpression of polyphenol oxidase in transgenic tomato plants. Planta 215, 239-247.

Malencic, D., Kiprovskia, B., Popovica, M., Prvulovica, D., Miladinović, J. and Djordjević, V. (2010): Changes in antioxidant systems in soybean as affected by Sclerotinia sclerotiorum (Lib.) de Bary. Plant Physiol. Biochem. 48, 903-908.

Marciano, P., Di Lenna, P. and Magro, P. (1983): Oxalic acid, cell wall-degrading enzymes and pH in pathogenesis and their significance in the virulence of two Sclerotinia sclerotiorum isolates on sunflower. Physiol. Plant Pathol. 22, 339-345.

McDowell, J. M. and Dangl, J. L. (2000): Signal transduction in the plant immune response. Trends in Biochem. Sci. 25, 79-82.

Nandeshkumar, P., Sudisha, J., Ramachandra, K. K., Prakas, H. S., Niranjana, S. R. and Shekar, S. H. (2008): Chitosan induced resistance to downy mildew in sunflower caused by Plasmopara halstedii. Physiol. Mol. Plant Pathol. 72, 188-194.

Oros, G. and Virányi, F. (1987): Glasshouse evaluation of fungicides for the control of sunflower downy mildew (Plasmopara halstedii). Ann. Appl. Biol. 110, 53-63.

Penninckx, I., Eggermont, K., Terras, F. R. G., Thomma, B., Samblanx, G. W. D., Buchala, A., Métraux, J. P., Manneqa, Y. M. and Broekaert, W. (1996): Pathogen-induced systemic activation of a plant defensin gene in arabidopsis follows a salicylic acid-independent pathway. The Plant Cell 8, 2309-2323. 
Pereira, L. F., Goodwin, P. H. and Erickson, L. (2000): Peroxidase activity during susceptible and resistant interactions between cassava (Manihot esculenta) and Xanthomonas axonopodis pv. manihotis and Xanthomonas cassavae. J. Phytopathol. 148, 575-578.

Purdy, L. H. (1979): Sclerotinia sclerotiorum: History, diseases and symptomatology, host range, geographic distribution, and impact. Phytopathology 69, 875-880.

Radwan, O., Mouzeyar, S., Venisse, J. S., Nicolas, P. and Bouzidi, M. F. (2005): Resistance of sunflower to the biotrophic oomycete Plasmopara halstedii is associated with a delayed hypersensitive response within the hypocotyls. J. Exp. Bot. 56, 2683-2693.

Rathmell, W. G. and Sequeira, L. (1974): Soluble peroxidase in fluid from the intercellular spaces of tobacco leaves. Plant Physiol 53, 317-318.

Roeckel-Drevet, P., Gagne, G., De Labrouhe, D. T., Dufaure, J. P., Nicolas, P. and Drevet, J. R. (1998): Molecular characterization, organ distribution and stress-mediated induction of two glutathione peroxidase encoding mRNAs in sunflower (Helianthus annuus). Physiol. Plant. 103, 385-394.

Saharan, G. S. and Mehta, N. (2008): Sclerotinia Diseases of Crop Plants: Biology, Ecology and Disease Management. LXII. Springer-Verlag GmbH, Heidelberg, pp. 41-45.

Sato, M. (1980): Inhibition by oxalates of spinach chloroplast phenolase in unfrozen and frozen states. Phytochemistry $19,1613-1617$.

Schouten, A., Tenberge, K. B., Vermeer, J., Stewart, J., Wagemakers, L., Williamson, B. and Van Kan, J. A. L. (2002): Functional analysis of an extracellular catalase of Botrytis cinerea. Molec. Plant Pathol. 3, 227-238.

Serrano, A. R., Del Castillo, J. L., Novo, J. J., Ocana, A. F. and Gomez-Rodriguez, M. V. (2007): Chitinase and peroxidase activities in sunflower hypocotyls: effects of BTH and inoculation with Plasmopara halstedii. Biol. Plant. 51, 149-152.

Shetty, P. N., Jorgensen, H. J. L., Jensen, J. D., Collinge, D. B. and Shekar, S. (2008): Roles of reactive oxygen species in interactions between plants and pathogens. Eur. J. Plant Pathol. 121, 267-280.

Solis, J., Medrano, G. and Ghislain, M. (2007): Inhibitory effect of a defensin gene from the andean crop maca (Lepidium meyenii) against Phytophthora infestans. J. Plant Physiol. 164, 1071-1082.

Spoel, S. H. and Dong, X. (2009): Making sense of hormone crosstalk during plant immune responses. Cell Host Microbe 3, 348-351.

Spoel, S. H. and Dong, X. (2012): How do plants achieve immunity? Defence without specialized immune cells. Nature Rev. Immunol. 12, 89-100.

Thipyapong, P., Hunt, M. D. and Steffens, J. C. (1995): Systemic wound induction of potato (Solanum tuberosum) polyphenol oxidase. Phytochemistry 40, 673-676.

Tiedemann, A. V. (1997): Evidence for a primary role of active oxygen species in induction of host cell death during infection of bean leaves with Botrytis cinerea. Physiol. Molec. Plant Pathol. 50, 151-166.

Urdangarin, M., Norero, N. S., Broekaert, W. F. and de la Canal, L. (2000): A defensin gene expressed in sunflower inflorescence. Plant Physiol. Biochem. 38, 253-258.

Virányi, F. and Gulya, T. (1996): Expression of resistance in Plasmopara halstedii-sunflower pathosystem. In: ISA Symposium I. Disease Tolerance in Sunflower, Bejing, 13 June 1996, pp. 14-21.

Wojtaszek, P. (1997): Oxidative burst: an early plant response to pathogen infection. Biochem. J. 322, 681-692. 
